\section{$1 \mathrm{D0945}$}

膜タンパク質骨格ダイナミックスと二次元結晶：部位 特異的 ${ }^{13} \mathrm{C}$ 固体高分解能 NMRによるバクテリオロ ドプシン変異体解析

○斉藤 㹈、土田 隆浩、荒川 規、山口悟、辻 暁（姫路工大 · 院理)

膜タンパク質は生体膜中にあって、信号認識、物質輸送、その他生体 維持に不可欠な種々の活動に関与している。われわれはこれまで進 めてきた典型的な膜タンパク質としてのバクテリオロドプシン（bR） の ${ }^{13} \mathrm{C}-\mathrm{NMR} に よ る$ 解析から、室温においては低温状態で得られる電 子顕微鏡像や $\mathrm{X}$ 線回折から得られる rigid な立体構造の描像ではなく、 部位によってその動きが著しく異なるへテロな構造であることを示し たり。bRは紫膜として三量体構造が集まった六方晶の二次元結晶を 形成している。しかし、特定のアミノ酸の変異によって、タンパク質 一脂質、タンパク質同士などの相互作用の变調をきたす可能性があ り、特にW80L、W12L 変異株においては、二次元結晶の崩壊、ある いは不全が生じることが予測される。実際、 $\left[3-{ }^{13} \mathrm{C}\right] \mathrm{Ala}$ 標識变異体の ${ }^{13} \mathrm{C}$-NMR スペクトルでは、信号の拡がりと相対的な脂質信号の上昇 が起こり、六方晶の崩壊または不全による単量体としての信号を観測 していることがわかる。一方、 $\left[1-^{\left.1{ }^{13} \mathrm{C}\right]} \cdot \mathrm{Ala}\right.$ 、Val 標識のこれら変異体の ${ }^{13} \mathrm{C}-\mathrm{NMR}$ スペクトルでは、膜質通へリックス部位の信号はほぼ完全 に消滅していることがわかった。この膜貫通へリックスの採らぎは、 マジック角回転周波数と干涉する $10^{4} \mathrm{~Hz}$ に達する。このように摇ら ぎの周波数は $10^{2} \mathrm{~Hz}$ から大幅に增大して扰り、脂質一ヘリックス間の 相互作用がタンパク質の摇らぎをコントロールしていることがわかっ た。このようなタンパク質の堅さを制御する因子としての脂質の役割 は極めて重要で、対象とする膜タンパク質の種類とオリゴマー化の程 度、脂質の種類がこれらを検討する上で極めて重要であることがわか る。

1) H.Saito et al., Annm. Rep. NMR Spectrose., 47, 39-108 (2002)

H.Saito, T.Tsuchida, T.Arakawa, S.Yamaguchi, S.Turi : Dynamics of membrane proteins without 2D crystal; Site-directed ${ }^{13} \mathrm{C}$ NMR study on bacteriorhodopsin and its mutants

\section{$1 \mathrm{D} 1015$}

\author{
ハロロドプシンの吸収波長制御機構に関する量子化 \\ 学的研究 \\ ○櫻井 実、坂田 圭子、齊藤 紫野、井上 義夫（東工大·生命 \\ 理工)
}

レチナールタンパク質の吸収波長制御機構は、実験的にも理論的にも 長い研究の歴史がある。溶液中の遊離レチナールシッフ塩基化合物の 波長とタンパク中の波長との差は、オプシンシフトと呼ばれるが、そ の主要な因子として対イオン效果があげられる。一般に、対イオンが プロトン化シッフ塩基の窒素原子から遠ざかると、 $\pi$ 電子の非局在化 のため、波長は長波長シフトする。しかしながら、興味あることに、 Halobacterium salinarum 由来のハロロドプシン（HR）では、対イオ ン (Cl-) の結合に伴って、わずか $10 \mathrm{~nm}$ であるが、長波長シフトする。 この現象は、タンパク質の場を考慮入れること無しに説明できない。 本研究では、タンパク質の電子分極の効果を考慮可能な QN/MM-CI 計算をこの問題に適用し、この異常な吸収波長シフトの機構を検討し た。H R 重原子の初期構造としてはX線結晶構造（PDB code:1E12） を用いた。構造最適化計算および一点計算には、MOZYME 法を用 いパラメータとしては AM1 法を用いた。Cl-イオン結合状態と非結 合状態の波長を、タンパク質を固定電荷で近似した場合、電子分極の 效果も取り込んだ場合について、比較した。その結果、電子分極を考 慮したときのみ、実験に対応する長波長シフトが再現できた。詳細な 解析により、異常シフトの原因の1つは発色団の励起に伴って生ずる タンパク質部分の電子分極と基底状態に扔ける電荷分布との静電的相 互作用にあることが判明した。これまでわれわれは、オプシンシフト の主原因の一つは、発色団の励起状態に対しタンパク質オプシンの電 子分極応答が起こることであることを指摘してきたが、HRについて もこれが確かめられた。

M. Sakurai, K. Sakata, S. Saito and Y. Ionone : Hybrid QM/MM-CI Study of the Alsorption Maximum of Halorhodopisin

\section{D1000}

バクテリオロドプシンの 145 番目のメチオニンを小 さな側鎖のアミノ酸に変化させると、115 番目のアス パラギン酸の $\mathrm{pK}$ 值が大きく減少する

○井原邦夫 1 、伊藤繁 ${ }^{2}$ 、向畑 恭男 ${ }^{3}$ ( ${ }^{1}$ 名大 $\cdot$ 遺伝子実験、 2 名大・院理・物理、3 高知工科大・物質環境システム)

バクテリオロドプシン（bR）の145番目の Metは、レチナール近傍に 位置する 21 アミノ酸残基の 1 つで、5本目のへリックスである Helix Eのほぼ央に位置している。この残基は、同じ光駆動性プロトンポ ンブであるアーキロドプシン 2 やクルックスロドプシンでは、Pheや Lenに変化している。バクテリオロドプシンの M145F, M145L 変異 体は、ほぼ野生型と同じであり、暗順応型でのレチナール異性体比だ けが異なっていた。ところが、この残基を側鎖の小さなアミノ酸であ る AlaやGlyに置換したものでは、吸収スペクトルの特徽が大きく変 化した。これは、野生型の bR の吸収スペクトルが、 $\mathrm{pH}$ や温度、塩 濃度には、全く影響されないのに対して、M145A 変異型では、大き く依存して変化するというものである。このスペクトル変化は、通常 の $560 \mathrm{~nm}$ 付近に吸収極大を持つフォームから $480 \mathrm{~nm}$ 付近に吸收極大 を持つフォームへの変化であるが、今回、 $\mathrm{pH}$ 変化によるスペクトル シフトが塩濃度依存的に 2 段階に分離できることと、差吸收スペクト 几の初期変化が、後半部分の変化と異なる事からこの変化が少なくと も2 種類の異なる過程からなっていることを、見いだした。さらに、 少なくとも一方の変化（主要な变化と考えている）がアスパラギン酸 の脱プロトン化であることが、DCCD(あるいは、その蛍光誘導体で ある NCD-4)の化学修飾によって推定でき、キモトリプシン分解断片 のアミノ酸分析と質量分析から、その修飾位置が 115 番目のアスパラ ギン酸であることを決定した。Met145は、Asp115 と空間的に離れて おり、直接相互作用する事は考えにくい。従って、M145Aの変異に よってレチナールポケットに空間が生じて、レチナール分子を介して 間接的にAsp115の近傍に空間が移り、そこに水分子が入ることでそ の $\mathrm{pK}$ 值が大きく減少したのではないだろうか？

K.Thara, S.Ito and Y.Mukohata : A mutation at a 145th Met of the bacteriorhodopsin to a small side chain amino acid causes a large pK value decrease of a 115 th Asp.

\section{$1 \mathrm{D} 1030$}

ホヤ幼生の視覚・脳神経系回路網の可視化 2－視細胞 から高次ニューロンへの投射

○川上功 ${ }^{1}$ 、堀江 健生 ${ }^{1}$ 、吉田 麗子 ${ }^{1}$ 、中川将司 ${ }^{1}$ 、吉原 良

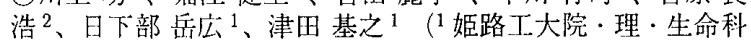
学、 2 理研・脳科学総合)

ホヤの幼生は、尾部に春索を持つオタマジャクシ型をしており、脳胞 に存在する感覚器官、眼点・平衡器を用いて、海中を遊泳する。カ夕 ユウレイボヤの幼生は、瞬化後約 4 時間目から着生・変態に至る迄の 間、光応答を示寸。また、光 (明暗) 刺激に対し、鋭敏化や慣れ等の 学習行動を示す。ホヤ幼生の中枢神経系を構成する細胞数は約 300 個 (内、神経練胞は約 100 個) と少数の練胞から構成されており、この 神経伝達回路を解明することは、脊椎動物の脳神経系を考える上で非 常に重要と考えられる。本研究では、その機能特異的な神経回路を同 定するため、経シナプス的にニューロン間を輸送される性質を持つ小 麦胚芽レタチン（WGA:wheat germ agglutinin）をレポーターに用い て、視細胞を起点とした神経回路の標識、可視化を試みた。方法とし ては、幼生の視細胞特異的に発現するアレスチン遺伝子の発現調節 領域下流にレポータ一遺伝子（WGA c.DNA）をつないだ融合遺伝子 を作成、この融合遺伝子をエレクトロポレーション法によりカタユウ レイボヤ卵に導入し、幼生の視細胞特異的にWGAを発現させる。抗 WGA 抗体を用いた免疫染色により、経シナプス的にニューロン間を 輸送されたWGAを検出することで、視細胞を起点とした神経回路の 可視化をおこなった。その結果、瞬化後 8 時間目の幼生では、視細胞 からの入力を受け、渾動神経節へと軸索をのばす二次ニューロンが観 察された。これらの結果と、神経系の特異的マーカ（シナプトタグミ ン等）を用いて同定された神経回路網との比較、発生に伴う軸索伸展 の観察、また、光坎答の頻度と WGA 輸送量との関係等を報告する。 